\title{
Grand Challenges in Cryospheric Sciences: Toward Better Predictability of Glaciers, Snow and Sea Ice
}

\author{
Regine Hock ${ }^{1,2 *}$, Jennifer K. Hutchings ${ }^{3}$ and Michael Lehning ${ }^{4}$ \\ ${ }^{1}$ Geophysical Institute, University of Alaska Fairbanks, Fairbanks, AK, United States, ${ }^{2}$ Department of Earth Sciences, \\ Uppsala University, Uppsala, Sweden, ${ }^{3}$ College of Earth Ocean and Atmospheric Sciences, Oregon State University, \\ Corvallis, OR, United States, ${ }^{4}$ Institute for Snow and Avalanche Research, Davos, Switzerland
}

Keywords: cryosphere, glaciers, ice sheets, snow, sea ice, modeling, climate

\section{OPEN ACCESS}

Edited by:

Valerio Acocella,

Roma Tre University, Italy

Reviewed by:

Steven L. Forman,

Baylor University, United States

Nick Van De Giesen,

Delft University of Technology,

Netherlands

Tómas Jóhannesson

Icelandic Meteorological Office,

Iceland

${ }^{*}$ Correspondence:

Regine Hock

rehock@alaska.edu

Specialty section:

This article was submitted to

Cryospheric Sciences,

a section of the journal

Frontiers in Earth Science

Received: 07 November 2016

Accepted: 20 July 2017

Published: 14 August 2017

Citation:

Hock R, Hutchings JK and Lehning M (2017) Grand Challenges in Cryospheric Sciences: Toward Better Predictability of Glaciers, Snow and Sea Ice. Front. Earth Sci. 5:64. doi: 10.3389/feart.2017.00064

\section{INTRODUCTION}

Cryospheric sciences encompass the study of frozen water in all forms, including glacier ice, seasonal snow, sea, lake, and river ice, and frozen ground. All components of the cryosphere are closely interlinked and coupled to other components of the Earth, in particular the climate system. Due to ongoing rapid changes in response to atmospheric and oceanographic warming, the cryosphere has received increased attention by the scientific community, policymakers, and the public. Widespread glacier retreat and mass loss, decrease in snow cover, decline in sea ice, and thawing permafrost are at the forefront of concern due to the range of possible major socio-economic, ecological, and environmental consequences. For developing efficient mitigation and adaption strategies one of the main challenges in cryospheric sciences is to make accurate predictions of anticipated changes on timescales relevant to policy-makers. This is inherently difficult due to the complex non-linear nature of cryospheric processes and feedback mechanisms. Despite major progress in recent years, currently, accurate predictions are hampered by insufficient observations, process understanding, and modeling capacities. These deficiencies need to be addressed to further the understanding and prediction of the cryosphere.

Here, we focus on glaciers, snow, and sea ice, and discuss some of the "Grand Challenges" related to the need for better understanding and predicting their changes due to anticipated climate change. We are fully aware that our subjective and non-exhaustive focus does not embrace the full range of challenges faced by the broad field of snow and ice research.

\section{GLACIERS AND ICE SHEETS}

\section{Recent Changes}

Glaciers around the world are losing mass at an accelerating pace with profound implications for global sea-level rise, global climate, local river systems, and their physical, biogeochemical, and ecological properties, as well as natural hazards. Observations indicate a consistent and largely homogenous trend of global retreat and shrinkage of the Earth's mountain glaciers, ice-shelf collapses in Antarctica, and an exceptional acceleration in ice flow and associated mass losses of outlet glaciers in Greenland and West Antarctica in response to atmospheric and ocean warming. These changes highlight the need for further capabilities to monitor, understand and predict the behavior of land ice and its interactions with the atmosphere and the oceans.

In the last decade, new remote sensing technologies and missions, such as NASA's Ice, Cloud, and land Elevation Satellite (IceSAT), the Gravity Recovery and Climate Experiment (GRACE), 
and the Operation IceBridge have revolutionized our ability to monitor the state and changes of land ice masses, in particular of the two huge ice sheets in Greenland and Antarctica, and glaciers in remote polar regions. These observations indicate that mass loss from glaciers and ice sheets has contributed approximately $60 \%$ of total global sea-level rise during the period 2003-2009 with roughly equal shares from the two ice sheets in Greenland and Antarctica combined $\left(259 \pm 28 \mathrm{Gt}^{-1} \mathrm{rar}^{-1}\right.$ or 0.71 $\pm 0.08 \mathrm{~mm}$ SLE (sea-level equivalent) year $^{-1}$ ) and all $\sim 200,000$ glaciers outside the ice sheets $\left(289 \pm 49 \mathrm{Gt}\right.$ year $^{-1}$ or $0.79 \pm$ 0.13 mm SLE year ${ }^{-1}$; Shepherd et al., 2012; Gardner et al., 2013), highlighting their socio-environmental relevance. Extending these estimates to cover the period April 2002-November 2014, Reager et al. (2016) find that the ice sheet contribution has increased considerably $\left(1.26 \mathrm{~mm}\right.$ SLE year $\left.{ }^{-1}\right)$, while the glacier contribution remained similar $\left(0.65 \mathrm{~mm} \mathrm{SLE} \mathrm{year}^{-1}\right)$. Hence, the share of the ice sheets relative to the mountain glacier contribution has risen. Their results also indicate that the rapidly increasing cryospheric contribution has partially been masked by an increase in water stored on land.

\section{Rapid Dynamic Changes}

The discovery that the ice sheets can change much faster than previously considered possible, took the glaciological community by surprise, rendering the ice sheets a "wild card" in any attempts to project future contributions to sea-level rise (Truffer and Fahnestock, 2007; Alley and Joughin, 2012). Some marineterminating outlet glaciers in Greenland have doubled or even tripled their speed (Joughin et al., 2004) in just a few years, accompanied by thinning and rapid retreat after years of stable front positions (Howat et al., 2007; Stearns and Hamilton, 2007). Flow acceleration has gradually expanded to the north (Rignot and Kanagaratnam, 2006). Some glaciers have then returned to "normal" flow speeds (Murray et al., 2010) indicating that rapid changes in either direction are possible within just a few years. The largely synchronous acceleration in ice flow over large areas is indicative of a common climatic (Joughin et al., 2008) or oceanic driver (Holland et al., 2008; Straneo et al., 2010), although the response to regional and local forcing is complex (Moon et al., 2012, 2014, 2015; Straneo et al., 2013).

Many Greenland outlet glaciers occupy deep troughs extending far inland below sea level setting the stage for inherently unstable glacier behavior. The situation is even more worrisome in West Antarctica, where most of the ice sheet is grounded below sea-level on an inland-sloping bed, providing a delicate setting prone for potential run-away effects once retreat is initiated (Joughin and Alley, 2011), as had been envisioned early on (Mercer, 1978). Rapid changes possibly indicative of such an ice sheet instability have recently been observed at Thwaites and Pine Island Glacier (Mouginot et al., 2014), which combined drain $\sim 5 \%$ of the Antarctic Ice Sheet. Ice-sheet simulations by De Conto and Pollard (2016) suggest that rapid mass loss from Antarctica due to marine ice-sheet instabilities may cause a meter of sea-level rise by 2100 and more than $15 \mathrm{~m}$ by 2500 . Studies investigating the observed dynamic thinning, grounding line retreat and net mass loss suggest that these changes may signal the onset of a collapse of the West Antarctic ice sheet (Favier et al., 2014; Joughin et al., 2014;
Rignot et al., 2014; Ritz et al., 2015). Once initiated, a yet not fully understood chain of feedback mechanisms may cascade: reduced buttressing of the upstream ice due to retreat causes ice speed-up, which leads to dynamic thinning and increased calving at the marine-terminating fronts, which in turn leads to further mass loss and retreat. Surface mass-balance processes do not trigger rapid changes directly, but enhanced surface melt has been identified as a precursor to catastrophic ice-shelf collapses (Banwell et al., 2013).

Overall, accelerated ice discharge into the oceans has tripled the mass loss of both ice sheets to $298 \pm 58 \mathrm{Gt}_{\text {year }}{ }^{-1}(0.83$ $\pm 0.16 \mathrm{~mm} \mathrm{year}^{-1}$ ) during 2000-2011, compared to the period 1992-2000 (Shepherd et al., 2012). Some estimates of multiyear averages of mass loss after 2009 exceed $350 \mathrm{Gt}$ year $^{-1}$ for Greenland (McMillan et al., 2014) and $150 \mathrm{Gt} \mathrm{year}^{-1}$ for Antarctica (Helm et al., 2014; Khan et al., 2015). Velicogna et al. (2014) found that the significant acceleration of ice sheet mass loss is driven mainly by a few subregions. Sutterley et al. (2014) found that the acceleration of mass loss in the Amundsen Sea area of West Antarctica is nearly 3 times larger during the period 2003-2009 than it was over 1992-2013.

The Fourth Assessment Report (AR4) of the Intergovernmental Panel on Climate Change (IPCC, 2007) pointed out that ice flow may be a key driver of rapid ice sheet change, but recognized that "quantitative projections cannot be made with confidence" mainly due to a lack of process understanding regarding rapid and possibly catastrophic and irreversible changes of ice sheets or parts thereof. The lack of adequate representation of these processes in the previous generation ice sheet models was considered the largest source of uncertainty in projecting twenty first century sea-level rise. In the wake of AR4 a wealth of new observations has been collected, and significant progress has been made in process understanding and the ability of models to account for couplings between ice sheets, ice streams and ice shelves, and their two-way interactions with the atmosphere, their subglacial environment and the ocean. However, models did not mature sufficiently for the Fifth Assessment Report (AR5; IPCC, 2013) to account explicitly for mass losses from rapid dynamic changes. Large uncertainties persist with regard to modeling and projecting ice sheet evolution and possible catastrophic contributions to sea-level change (Vaughan and Arthern, 2007).

Insufficient understanding of the mechanisms of the ice sheets' rapid dynamic changes remains the main culprit in the quest for better projections. Such changes cannot be triggered by the slow flow of ice by internal deformation, which is relatively well understood and represented in models. Hence rapid change can only be caused by interactions of the ice with its boundaries. Better understanding and proper implementation of the relevant processes, in particular at the ice-ocean and ice-bed interface, into predictive models are among the most critical challenges in reducing uncertainties in projections of the ice sheet contribution to sea-level rise.

\section{Ice-Ocean Interface}

Evidence is mounting that the ice-ocean interface is crucial to understanding rapid glacier change. Recent results indicate that much of the ablation at marine-terminating glaciers and 
beneath ice shelves is due to submarine melting rather than iceberg calving (Rignot and Jacobs, 2002; Bartholomaus et al., 2013; Truffer and Motyka, 2016), highlighting the role of the ocean, in particular ocean temperatures, in ice sheet and glacier behavior and adding further complexity to prognostic modeling. For example, Motyka et al. (2011) found specific melt rates exceeding $200 \mathrm{~m} \mathrm{year}^{-1}$ beneath the floating tongue of Jakobshavn (Ilulissat) glacier, Greenland, in the mid-1980s. Melt rates increased by $\sim 25 \%$ in the following decade. Holland et al. (2008) were among the first to recognize that ocean warming may play a major role in triggering the rapid changes in Greenland. Delivery of warm ocean waters to the glacier fronts increases submarine melt rates, which in turn precipitate a chain of feedbacks that lead to increased flow speeds, calving rates and ice discharge into the ocean. Recent observational studies indicate that near-terminus subglacial freshwater discharge exerts a major control on submarine melt rates (Motyka et al., 2013), confirming earlier theoretical (Jenkins, 2011), and numerical studies (Xu et al., 2012).

In addition to untangling the precise mechanisms at the ice-ocean boundary and their coupling, it is an even greater challenge to implement the complexity of the coupled processes of mechanical calving, submarine melt, and up-glacier feedbacks into prognostic models (O'Leary and Christoffersen, 2013; Straneo et al., 2013; Cook et al., 2014). Despite increased attention to the ice-ocean interface and unprecedented observational detail (Fried et al., 2015) the system is still not well understood; this poses significant challenges to modeling (Slater et al., 2015). Observations of all relevant components and an interdisciplinary approach including glaciologists and oceanographers will be key to success.

The glaciers outside the ice sheets are mainly driven by surface mass balance processes, but $38 \%$ of their total area drains through marine-terminating glaciers (Gardner et al., 2013). The role of these glaciers in global mass budgets remains largely elusive, although a few regional estimates exist (see summary in Huss and Hock, 2015). Unstable retreat similar to those observed on the ice sheet outlet glaciers has been observed on non-polar glaciers, such as Columbia Glacier in Alaska (McNabb et al., 2012). Hence, such glaciers provide valuable analogs for ice sheet processes (Post et al., 2011). Research at these far more accessible and logistically less challenging mountain glacier systems can help shed light on the processes that are responsible for rapid changes of the ice sheets' marine-terminating glaciers.

\section{Bed Interactions}

The basal boundary and its effects on ice flow are also poorly known, due to the complexity of the processes involved and the inaccessibility of the glacier bed. The presence of subglacial and englacial water add to the complexity (Chu, 2014); frictional drag at the bed can vary greatly in space and time in response to basal water fluctuations, as has been studied extensively for mountain glaciers (Iken and Bindschadler, 1986). Zwally et al. (2002) linked ice sheet flow acceleration in Greenland to basal lubrication caused by atmospherically induced increased melt reaching the glacier bed. The study triggered a wave of recent observational and theoretical investigations, and provoked much controversy on the role of the subglacial boundary in explaining rapid ice sheet changes (Meierbachtol et al., 2013). While some studies show substantial increase in surface speeds, in particular over land-terminating margins on a seasonal basis (Palmer et al., 2011), others show decreases in ice speed on multi-year timescales, despite increased melt input (van de Wal et al., 2008; Sundal et al., 2011; Tedstone et al., 2015). These apparently conflicting results are consistent with the notion that subglacial drainage configurations and their efficiency to transmit water vary considerably in space and time (Fountain and Walder, 1998), triggering opposing responses in ice speed to increased water input.

While these results provide support that ice flow is affected by water at its bed, the collective evidence indicates that basal lubrication cannot explain the scope of the observed rapid outlet glacier changes in Greenland and Antarctica. However, the recent discovery of widespread connectivity of subglacial lakes below the Antarctic ice sheet and surprisingly rapid changes in lake storage by drainage into neighboring lakes (Wingham et al., 2006; Fricker et al., 2007) indicates that even in Antarctica, where surface melt is largely negligible, the lower boundary affects the slipperiness at the base of the ice sheet and thus ice speed. Model results indicate that $55 \%$ of the grounded part of the Antarctic ice sheet is at pressure melting point (Pattyn, 2010).

Despite recent promising theoretical advances, the inclusion of process-based subglacial hydrology models into ice sheet models is still in an early stage of development. Models generally do not account for water transport from the surface to the bed or lateral water flow along the ice-bed interface. Although some recent progress has been made (Schoof, 2010; Bueler and Pelt, 2015), substantial challenges remain in linking basal stresses to ice motion, and modeling the effect of increased meltwater input on ice discharge. A definitive sliding law, relating basal motion to basal stress and water pressure is still lacking, and may in fact not exist. This is partly due to the heterogeneity of the glacier bed, which can consist of relatively clean bedrock or subglacial till of various granularity.

\section{Surface Processes}

Processes at the surface-atmosphere boundary (snow accumulation, surface melt) determine the surface mass balance, which constitutes another important boundary condition for glacier and ice sheet behavior. The physical processes are relatively well-understood (Hock, 2005); however, quantifying recent and future surface mass changes still presents a major challenge. For example, ice-sheet wide annual surface mass balances in Greenland derived from regional climate models deviate by up to a factor of two (e.g., Fettweis et al., 2008; Ettema et al., 2009), in particular due to difficulties in modeling snow precipitation (see Section Snow Accumulation). This problem is only exacerbated in the topographically complex mountain ranges that host non-polar glaciers.

Refreezing is a major component of the mass budget, in particular on ice sheets and high-latitude glaciers. Modeling indicates that $\sim 40 \%$ of the total surface melt in Greenland may refreeze (Van Angelen et al., 2013). With atmospheric warming, refreezing may initially increase due to increased melt, 
but eventually it may decrease due to subsurface warming and decreasing pore space. Storage of water in firn may temporarily buffer the contribution of meltwater to sea-level rise (Harper et al., 2012). Modeling needs to account for the subsurface spatio- and temporal variability in temperature, water content and density; however, despite recent observational advances (Forster et al., 2014; Machguth et al., 2016), these processes are often oversimplified, and therefore poorly modeled in ice-sheet or climate models.

To account for feedbacks with the climate system through changes in surface elevation, albedo and freshwater input into the ocean, it is important to fully couple ice-sheet and (possibly also glacier) models to Atmospheric-Ocean General Circulation Models. However, currently most ice-sheet models are stand-alone models without two-way coupling (Vizcaino, 2014; Vizcaino et al., 2015). The necessary large computational resources are an additional barrier to progress in fully coupled modeling. Similarly, downscaling typically coarse-scale climate data to the glacier scale remains a major challenge in modeling and projecting mountain glacier behavior (Ziemen et al., 2016).

\section{Observations}

Lack of observational data is still a major issue in assessing and predicting change. Glaciological datasets are often short in duration or cover limited areas, although tremendous progress has been made recently. A wide suite of large-scale data sets of the Earth's glaciers at unprecedented spatial and temporal resolution have been collected in the last decade, including surface velocities (Rignot et al., 2011; Moon et al., 2012; Fahnestock et al., 2016), surface elevations (Howat et al., 2014), surface elevation changes (Pritchard et al., 2009), ice sheet bedrock (Bamber et al., 2013), and ice thicknesses (Fretwell et al., 2013). The first complete inventory of all glaciers outside the ice sheets, the so-called Randolph Glacier Inventory (RGI; Pfeffer et al., 2014) combining data from GLIMS (Global Land Ice Measurement from Space) (Raup et al., 2007; Kargel et al., 2014) with new data to achieve complete coverage globally, has removed a major obstacle in modeling these glacier systems. However, lack of accurate bed topography data, and thus initial ice volume, introduces considerable uncertainties in their modeling.

High-resolution data are needed in particular at the ice-ocean interface. In Greenland the fjord arms are largely unmapped, and in Antarctica, the topography under the ice shelves, which strongly affects sub-ice shelf melt rates (Hattermann et al., 2014), is poorly known. Also, too little is known about ocean properties and their short-term variability. Data collection is not trivial given that this domain is often choked with icebergs calling for the development of innovative data collection techniques, such as attaching instruments to deep-diving seals (Sutherland et al., 2013). Data revealing the past, for example, from ice or sediment cores, are essential to put current changes in context, and to validate models. Collecting data on basal drag, thermal conditions and subglacial waterflow at the subglacial boundary will remain difficult, if not impossible. But recent advances in inverting at least some of these properties from surface data are promising (McNabb et al., 2012; Morlighem et al., 2014; Brinkerhoff et al., 2016; Farinotti et al., 2017).

\section{SNOW}

Snow is a fascinating mixture of ice, water, water vapor, and air. It is the most ephemeral part of the cryosphere, a fact that is intuitively appreciated when considering a dendrite of fresh snow in the palm of one's hand. Snow on Earth has a limited lifetime, because it either melts or consolidates into ice, and it is a highly dynamic material, which can change its density by an order of magnitude within days. Finally, fresh snow reflects almost all incoming short wave radiation, while it acts as an almost perfect black body in the infrared part of the spectrum.

\section{Snow Microstructure}

Research on snow microstructure has exploded in recent years, because it is increasingly recognized that important mechanical, thermodynamical, and electromagnetic properties of snow cannot be predicted without a proper consideration of snow microstructure (Aoki et al., 2011; Lowe et al., 2013). Furthermore new observational technologies such as micro-computer-tomography (Schleef and Lowe, 2013), optical spectrometry (DUFISS) (Gallet et al., 2009) or snow micropenetrometry (Lowe and van Herwijnen, 2012), have made it possible to quantify snow microstructural effects. What is missing is the development of a unifying theory, describing the physical properties and behavior of snow at a larger scale based on laws of snow microstructure development. While it is quite clear that such a theory will include-next to density - the specific surface area of the snow grains and curvature terms characterizing the snow-pore interface, it remains to be shown that a predictive microstructure model based on density, surface area and mean and/or Gaussian curvature is able to replace current more empirical microstructure models (Lehning et al., 2002). This step is currently being addressed in the snow microstructure community (e.g., Krol and Löwe, 2016) and will lead to the development of new snow models, which are able to describe mechanical and electromagnetic properties of snow in a more physical way.

\section{Snow Accumulation}

Snow accumulation in mountainous regions, as well as on ice sheets and sea ice continues to be insufficiently understood (see also Section Surface Processes). The mountain snowpack is a major source of freshwater for many arid and semi-arid regions worldwide, but researchers still struggle to reliably estimate the amount of snow stored in the high alpine regions and how much water can be expected downstream. A major source of uncertainty comes from the fact that measuring (snow) precipitation in the high alpine zone is extremely difficult, if not impossible, given the windy conditions and limited infrastructure available in these areas (Sevruk and Mieglitz, 2002; Sevruk et al., 2009). Recent progress in remote sensing of snow depth distribution is helping to put more constraints on mountain snow cover and precipitation. The analysis of spatial snow depth maps has revealed reduced snow amounts at high elevations (Grunewald et al., 2014; Kirchner et al., 2014), but scientists are only starting to investigate the links to precipitation patterns 
(Mott et al., 2014). It is therefore critically important to intensify efforts to better quantify precipitation and related available snow and water resources in the high alpine zone.

The problems described above are aggravated in polar regions, particularly in Antarctica, due to continuous high winds and low temperatures. Smaller errors in snow accumulation lead to large errors in the total ice sheet mass budget due to the enormous area of the ice sheet (Zwally and Giovinetto, 2011). Errors in accumulation estimation stem from very sparse measurements of precipitation in both polar regions together with an unknown accuracy of precipitation predictions by weather models. Windblown snow adds uncertainty; it results either in redistribution or loss of snow (e.g., open water leads in sea ice). Drifting and blowing snow also results in an unknown amount of sublimation, reducing the total mass before final deposition.

Larger-scale models of ice sheets, glaciers, and sea ice typically treat snow processes at the surface of these ice masses in a rudimentary way, and at an inadequate resolution for calculating, for example, a flux divergence of blowing and drifting snow. While the most advanced models such as MAR (Gallee et al., 2013; Amory et al., 2015) or RACMO (Lenaerts et al., 2012) implement parameterizations of the complex snow processes, quantitative validation is challenging. The community agrees that potential calculation errors are large, and critically influence the modeled total mass balance. One of the most critical processes is drifting and blowing snow, but it is largely unknown how much of the snowfall is permanently deposited and ultimately incorporated in the ice mass (Zwaaftink et al., 2013). Only recently have regional climate models, applied to the ice sheets, started to include a more physical description of firn processes (Van Angelen et al., 2013) and snow redistribution by wind (Lenaerts et al., 2012).

\section{Snow Ablation}

Snow melt and energy balance have been investigated over decades and are generally well understood. However, snow melt models often rely on erroneous meteorological input data (Schlögl et al., 2016), either because the measurements are spatially not representative or because input is taken from meteorological models, which insufficiently resolve boundary layer feedbacks. These feedback effects have been studied over glaciers with respect to katabatic wind formation and associated temperature effects (Greuell and Böhm, 1998; Shea and Moore, 2010). Recent results show how local flow features can change the turbulent heat fluxes (Mott et al., 2015), and that terrain sheltering has significant small-scale effects on melt efficiency (Mott et al., 2016). It is generally accepted that regional melt and therefore also catchment runoff (Cullather et al., 2016) can be well described with calibrated models, often using empirical temperature index methods for snow melt. At the same time, physics-based energy balance models, which are preferable for their transferability to other environments and future climates, have shown a high sensitivity to meteorological input (Schlögl et al., 2016). This remains a challenge to be addressed in the future.

\section{Snow Representation in Earth System, Climate and Weather Models}

The discussion above already suggests some of the difficulties in dealing with the thin and highly dynamic yet important snow component in larger-scale models. Misrepresenting the massive influence that snow exerts on the atmosphere and the soils will strongly bias model results (Beer, 2016). Snow representation in larger-scale models generally does not correctly reproduce the effect of snow on the atmosphere or ground correctly (Van Angelen et al., 2012). To limit the detrimental effect of an insufficient snow representation, some meteorological models (e.g., COSMO, Baldauf et al., 2011) assimilate snowcovered area, which can be estimated from a combination of ground and satellite observations. This produces acceptable results for short-term forecasting, but it remains a challenge to have an adequate representation of snow dynamics in largerscale models. Assimilation also does not solve the problem of insufficiently representing the effects of snow on other model components.

\section{Snow and Climate Change}

Global warming naturally has a large impact on snow dynamics impacting the duration of snow cover and timing of runoff production. Anticipated changes include a shift from snow to liquid precipitation and a potential increase in total precipitation (Lenaerts et al., 2013). More snow accumulation may offset increased ablation of ice sheets as long as it remains sufficiently cold, as has been shown to be important locally in certain regions (e.g., Schmucki et al., 2015). However, future snow changes are currently not modeled well on a global scale. Due to the difficulty to correctly represent snow dynamics in climate models, as discussed above, it is challenging to make reliable predictions on future snow and its feedback effects on the atmosphere and soils. Locally, water resources and tourist industries are affected by future snow changes. Globally, sea level rise and positive feedback mechanisms via release of carbon or methane following permafrost thaw are of major concern.

\section{SEA ICE}

Sea ice covers between 4 and $6 \%$ of the Earth's oceans, with a large seasonal cycle that profoundly impacts the climate of the polar regions and planet. Seasonality and interannual variability of pack ice differ between the poles. The Arctic Ocean is confined by land, such that its seasonal cycle in ice cover has smaller amplitude than the Southern Ocean (Eisenman, 2010). The Arctic experiences a continental climate in winter as the seaice pack impedes heat and moisture fluxes to the atmosphere. In contrast, the Antarctic sea-ice pack is constrained by the circumpolar current, extends to lower latitudes, and experiences heavier snowfall, which contributes to ice mass and a larger seasonal cycle in ice extent.

Sea ice plays an important role in regulating global climate. Loss of ice amplifies changes in radiative forcing, enhancing ice loss and warming, and thus represents a positive feedback in a warming climate. The loss of sea ice is attributed to be one 
of the main factors explaining the Arctic Amplification (Screen and Simmonds, 2010), in which surface temperature increases are observed to be twice as large in the Arctic compared to the global average (Polyakov et al., 2003; Bekryaev et al., 2010). Seaice loss increases solar absorption in the ocean (Perovich et al., 2011) and momentum transfer from wind into the ocean (Martin et al., 2014), leading to the speculation that sea-ice variability can be linked to multi-decadal variability in ocean circulation (Giles et al., 2012).

Identifying the magnitude and direction of feedbacks involving the ice surface energy balances in the current, past and future climates is central to unraveling the role of sea ice in the Earth's climate system. These feedbacks control seasonal, interannual, and longer-scale variability of the sea-ice pack, and their related climate sensitivities impact the polar oceans, atmosphere, land and ecosystems; and hence global climate.

\section{Recent Sea-Ice Changes}

There has been over $50 \%$ loss of sea-ice volume from the Arctic since 1979 (Schweiger et al., 2011; updated to 2015), which is primarily manifested as a loss of perennial ice area (Maslanik et al., 2011) through enhanced transpolar ice drift events (Nghiem et al., 2007), export to the Greenland-IcelandNorwegian Sea (Smedsrud et al., 2017), and increased melting within the Arctic (Kwok and Cunningham, 2010). The Antarctic has experienced a slight increase in sea-ice extent, but with large zonal variability, with increasing ice extent in the Ross Sea and decreasing extent in the Amundsen-Bellinghausen Sea (Turner et al., 2015). Less is known regarding variability in Antarctic ice thickness and volume.

The decrease in Arctic sea ice is happening at a time of increasing economic interest in mineral exploration, transport and tourism across the region (AMAP, 2004). There is increasing need for improved ice forecasting and accurate projection for strategic planning, as expected changes may increase hazards to human activity in the sea-ice pack (Stewart et al., 2007). The time scale needed to assist governmental and industry planning range from 10 to 50 years ahead. This presents one of the largest challenges to the sea-ice observers and modelers: nonlinear dynamics in the climate system impede model predictions of the sea-ice change over timescales longer than 2-10 years (Blanchard-Wrigglesworth et al., 2011; Guemas et al., 2014).

\section{Sea-Ice Thickness}

Until recently, one of the most significant challenges of the seaice community has been global observation of ice thickness. With satellite monitoring of ice thickness now available (Laxon et al., 2003), the challenge has moved to understanding biases in the measurement method. This has led to a need to better characterize the snow cover on sea ice, as a lack of information about snow thickness is the largest cause of uncertainty in seaice thickness measurements (Kwok and Cunningham, 2008). The lack of information about ice thickness is no longer the leading cause for uncertainty in appropriate model parameterizations. Uncertainty in projection of sea-ice change over the coming century is mainly attributed to a number of physical processes, outlined in Section Observation and Model Needs, that are inadequately constrained by current observational data.

\section{Sea Ice in Climate Models}

The observed recent changes in Arctic sea-ice pack are better represented in the climate models of IPCC's AR5 compared to AR4 due to improvements to sea-ice thermodynamic parameterizations in AR5 (Stroeve et al., 2012). However, these improvements have not decreased the spread in model realizations. Part of the uncertainty lies in natural variability in the Earth system, since predictions of sea ice are most uncertain on decadal timescales (Blanchard-Wrigglesworth et al., 2011).

Attribution of recent sea-ice loss in the Arctic has been called a "Grand Challenge" of climate science (Kattsov et al., 2010). To meet this challenge, we need to be able to accurately simulate the seasonality in the feedbacks controlling sea-ice mass balance. To do so we need better observational data constraining these feedbacks, which are related to coupled processes between the upper ocean, sea ice and atmosphere. In particular we do not know how heterogeneity in the sea-ice cover impacts the radiative, sensible and latent heat fluxes from the surfaces. Uncertainty in cloud properties results in significant uncertainty in downwelling longwave radiation flux at the ice-ocean surface.

\section{Uncertainty in the Surface Energy Balance of Sea Ice}

Sea-ice has the largest seasonal cycle in mass of all cryosphere components. This seasonality is controlled by the balance of positive and negative feedbacks to ice thickness that change over the year as the surface energy balance goes from net positive in summer to negative in winter. Interannual variability in seaice thickness reflects variability in atmosphere and ocean, and indicates high sensitivity of the sea-ice cover to the surface energy balance. The average change in heat budget to explain the loss of ice over the last three decades is only about $1 \mathrm{Wm}^{-2}$ (Kwok and Untersteiner, 2011). Attribution of this additional heat is a matter of current debate.

Positive feedbacks on sea-ice loss are numerous, and are counteracted by the large negative feedback caused by ice thickening in winter. Representing the variability from these competing processes is important for correctly modeling climate sensitivity (Notz, 2015). Carmack et al. (2015) document the terms that have most uncertainty in the sea-ice surface energy budget. The atmospheric flux components introduce an order of $10 \mathrm{Wm}^{-2}$ uncertainty, which is more than enough to explain recent ice loss. Inability to constrain these fluxes in models contributes to the wide variability in sea-ice seasonality, interannual variability and trends in climate models. The uncertainty in ocean heat flux to the sea-ice pack is another, smaller, yet significant contributor.

A review of recent advances in parameterizing sea iceatmosphere processes is presented by Vihma et al. (2014). Carmack et al. (2015) include a review of sea ice-ocean processes. Climate model sensitivity is related to the representation of sea-ice processes, and models present wide variability in their representation of the sensitivity of sea ice to greenhouse gas 
forcing (Stroeve and Notz, 2015). The processes that contribute to this uncertainty are outlined below.

\section{Positive Feedbacks}

Observing recent changes of the sea-ice pack give us some indications, though not conclusive, of the feedbacks driving these changes. We know that solar absorption through the increasing open water area in the Arctic during summer (Perovich et al., 2011) may be increasingly delaying freeze-up for areas of the northern hemisphere ice pack (Steele et al., 2010; Jackson et al., 2012; Timmermans, 2015). This is associated with an increase in oceanic heat and moisture flux to the atmosphere, with unknown impacts on atmospheric stability (Overland and Wang, 2010). At the same time, the sea-ice pack is more open, and its areal extent reduced, increasing wind-tress transfer into the ocean (Martin et al., 2014). Increased wind combined with increased geostrophic ocean currents around the Beaufort Gyre since 2007 (Giles et al., 2012; McPhee, 2013) are linked to increased ice drift rates in the Beaufort Sea (Petty et al., 2016), and to pooling of freshwater in the upper water column, increasing stratification, in the Canada Basin (Morison et al., 2012). Decreasing sea-ice mass implicit from the observational evidence has been associated with: changes in ice drift (Rigor and Wallace, 2004; Nghiem et al., 2007) and increased divergence of the pack (Hutchings and Perovich, 2015), both of which precondition the pack for enhanced melt; changes in cloudiness (Kay et al., 2008), which affects both shortwave and longwave radiation balance; and increasing Pacific summer water inflow to the Chukchi Sea (Shimada et al., 2006; Woodgate et al., 2010, 2012). Also, an increasing Atlantic water inflow to the eastern Arctic (Polyakov et al., 2012) is another heat source, that may reach the ice through various mixing mechanisms (Carmack et al., 2015). Variability in Atlantic water in the Arctic may be related to the Atlantic Multidecadal Oscillation and a similar period of oscillation in the sea-ice pack (Miles et al., 2014). Heat released from the Atlantic water has recently been identified as a significant contributor to sea-ice loss (Polyakov et al., 2017).

Perhaps the most fundamental gap in our knowledge of sea-ice feedbacks relates to our poor understanding of polar clouds. Kay and Gettelman (2009) find that changes in cloud cover cannot explain the increasing ice-albedo feedback during summer, but they probably contribute to increasing longwave cloud feedback in fall. This longwave feedback is particularly difficult to model. The distribution of ice and water droplet size distribution is not well known in Arctic clouds; the sensitivity of sea ice in fully coupled models to this uncertainty in cloud parameterization is as large as the observed sea-ice reduction (Karlsson and Svensson, 2013; Pithan et al., 2014). Our inability to constrain one of the leading-order terms in the ice-ocean surface energy budget, can result in model ranges for ice thickness much different from those observed. Limitations in our knowledge of Arctic cloud composition are such that cloud parameterizations are weakly constrained, and cloud longwave emission biases may be offset by biases in the sea-ice model. In summer, the longwave feedback is closely connected to the albedo feedback (Karlsson and Svensson, 2013), as increasing ice loss results in increasing longwave emission from the surface and moisture flux to the atmosphere.

From the leading-order problem of resolving cloud properties and the downwelling longwave radiation, there is an array of cascading uncertainties, with the surface-cloud feedback being dependent on several physical processes that may be inaccurately parameterized in models. This leads us to another fundamental feedback in the system, the ice-albedo feedback. The albedo of sea ice may be biased in models as we do not consider the disparate evolution of melt pond fraction on ice of varying type and surface roughness (Fetterer and Untersteiner, 1998), snow cover (Petrich et al., 2012; Skyllingstad et al., 2015), and time in the melt season (Eicken et al., 2004). The spatial variability of the ice surface morphology is not well-represented at the sub-grid scale in climate models, and the seasonal transitions of this surface and its albedo are only recently being considered in models (Flocco et al., 2010). Observations suggest changes in melt-pond coverage may be an important component of the recently observed Arctic sea-ice loss (Flocco et al., 2012; Rösel and Kaleschke, 2012), since light transmittance through ponds enhances ice melt (Itoh et al., 2011; Nicolaus et al., 2012). Parameterization of melt ponds relies on knowing the ice surface morphology and snow cover, which are controlled by the continuous deformation of the sea-ice pack and snow blowing over the rough surface.

\section{Negative Feedbacks}

In considering the large positive feedbacks in the sea-ice system the reader is probably wondering why the Arctic has not lost its sea ice entirely. As mentioned earlier, there are strong negative feedbacks in the sea-ice system balancing the strong positive feedbacks (Notz, 2015). Some of these feedbacks increase as we move from a perennial to a seasonal sea-ice pack. Rapid ice growth at the onset of winter recovers the pack to a near equilibrium level ice thickness within several months. Ice is insulating, and snowfall insulates further, such that open water and thin ice regions grow ice faster than regions of thicker snow and ice.

Increasing positive feedbacks to ice melt are offset by increased ice growth. The enhanced seasonal cycle in ice volume results in increased amplitude of the seasonal cycle in freshwater input and uptake from the upper ocean, while increasing brine rejection. This potentially increases stability of the upper ocean, which is a negative feedback to ice loss. In the Antarctic, this mechanism may actually be assisted by the injection of continental ice sheet meltwater into the upper ocean (Bintanja et al., 2013), hindering heat flux to the ice base and increasing ice thickness regionally. It is river inflow into the Arctic, and the formation of a halocline that allows a perennial ice cover to exist (Carmack, 1990), and freshwater pooling in the Canada basin is a negative feedback that helps sustain the sea-ice pack.

\section{Upper-Ocean Heat Budget}

While ocean stratification is a large-scale feature, there is considerable spatial heterogeneity in the sea-ice basal melt rate (Maykut, 1982). Variable ocean-ice heat flux (e.g., Krishfield and Perovich, 2005; McPhee et al., 2005) has several causes. Sea ice melt creates a fresh layer at the top of the ocean that is warmed 
by solar energy, and further melts ice [discussed for example in Vivier et al. (2016)]. This heat also becomes entrained into a near surface layer of warm water (Jackson et al., 2010) which is mixed upwards during storms (Jackson et al., 2012; Zhang et al., 2013), melting ice or delaying ice freeze-up. Other oceanic dynamic processes can bring heat upward from depth transported into the Arctic from the Atlantic and Pacific (Carmack et al., 2015). Processes that provide the majority of heat flux to the ice are micro- and mesoscale. Quantifying the partitioning of solar input to the upper ocean between ice melt and delay in freeze up requires parameterization of these stratification and mixing processes.

\section{Preconditioning the Sea Ice-Ocean Energy Budget}

Feedbacks related to sea-ice loss or growth are modulated by the thickness distribution of the sea-ice pack, which influences atmospheric and ocean drag. The ice thickness distribution and roughness is controlled by the history of ice drift and horizontal deformation (divergence and shear), growth and melt. The deformation occurs through plastic failure, whereby pack ice can only sustain stresses below its strength without permanent deformation. This is a dissipative term in the kinetic energy balance. In the momentum balance the divergence of the ice stress field is called the ice interaction, and the relationship between stress and deformation follows a rheological model. This parameterization of deformation of sea ice is poorly constrained, due to the difficulty in defining ice strength on the scale of model grid cells.

Model ice strength is typically related to the ice thickness, which is an indication of ice age and hence the properties that impact strength, including salinity and microstructure of the ice. However these relationships have not been assessed in the context of the model ability to simulate features key to the surface fluxes (leads fraction for example). Surface roughness is typically neglected when calculating oceanic and atmospheric drag on the ice, although a parameterization has been implemented in one sea-ice model (Tsamados et al., 2014). The ice interaction term, and drag parameterizations for wind and ocean surface stresses in the force balance on pack ice are often tuned in models to best reproduce observed ice drift, extent, and thickness. This does not ensure deformation fields are accurately simulated (Kwok et al., 2008), or that wind stress is appropriately partitioned between driving ice deformation and ocean currents, which has implications for the surface energy balance. For example, increased opening may result in enhancement of the albedo feedback (Hutchings and Perovich, 2015).

Misrepresentation of ice kinematics profoundly impacts the redistribution of ice thickness to thin (lead) and thick (ridged/rafted) ice. Dynamic thinning or thickening of pack ice is either a positive or negative feedback to the end of summer ice volume, but the nature of these feedbacks is currently not well known.

\section{Observation and Model Needs}

In order to simulate observed variability in the sea-ice pack volume, the ice and ocean surface energy balance needs to be accurate. This requires accurate simulation of all the competing feedbacks in the system, which range from strongly negative to strongly positive. Parameterizing these processes will require improved observations. In particular there is need for: improved knowledge of the composition of Arctic clouds throughout the year; identification of melt pond fraction and the processes driving melt pond evolution on ice of varying topography and snow cover; improved representation of sea-ice deformation in models; and improved understanding of how heterogeneity in sea ice impacts atmospheric and oceanic stability and related fluxes across the ice surface.

\section{Modeling Challenges}

At the heart of improving the representation of the sensitivity of sea ice to the surface energy balance is improving our ability to realistically simulate interannual variability in sea-ice mass. Climate models extending into the next century project ice loss events that occur on similar timescales as the reduction in Arctic ice volume observed in the last decade (Holland et al., 2006). Diagnosis of feedbacks controlling such events shows a variety of mechanisms that enhance ice loss (Holland et al., 2006; Vavrus et al., 2011). Climate models on average demonstrate lower seaice sensitivity to climate forcing than observations suggest. So while the IPCC model ensembles represent a large spread in future projection of sea-ice state, one can question whether this spread of realizations is realistic given that positive and negative feedbacks to ice mass in the system are likely to be larger than simulated.

Identifying the magnitudes of the leading order feedbacks in the climate system is crucial to improve climate model capabilities in projecting climate changes. The nature of sea-ice loss events, the rate of ice change and interannual variability is controlled by feedbacks that are poorly constrained in climate models. Rapid ice loss events are highly likely, and we are currently experiencing one. The time scale and mechanisms for these events are poorly resolved in current climate models.

\section{SYNTHESIS: FACING THE CHALLENGES}

All components of the cryosphere are currently undergoing rapid changes in response to atmospheric warming, and the challenges here are multi-faceted. Major challenges in the quest for better predictability of the cryosphere remain in three main areas that are intrinsically connected: observations, process understanding and modeling capabilities. Tremendous progress in observational capabilities, in particular due to recently launched satellites, such as GRACE, CryoSat-2 and Sentinel-2, has enabled us to measure and monitor cryospheric changes at unprecedented spatial and temporal scales. Despite these advances there is a pressing need for more high-resolution and high-quality data. Field campaigns need to be focused in critical areas to address the major deficits in our understanding of processes and feedbacks within the climate-cryosphere system that are critical for modeling future change. Rather than studying individual components in isolation, this is best accomplished in a "system approach" at carefully chosen study sites that include all relevant system boundaries and interactions (e.g., climate-ocean-cryosphere). 
Specific aspects, such as characterizing polar clouds and the impact of changing morphology on sea-ice albedo, are disciplinary problems. Yet there is an increasing need to coordinate across disciplines to quantify relevant processes and feedbacks in the system. For example, sea-ice dynamics can be both a negative and positive feedback to summer ice loss that varies spatially, seasonally, and with ice morphology. A pack of increased mobility may open more growing areas of thin ice that melt out early in the melt season, enhancing summer ice melt; but the pack may also open and close more to create larger areas of thicker, ridged, and eventually hummocked ice that is more resilient to complete melt. To characterize the magnitude of these feedbacks requires coordinated instrumental deployments by those studying sea-ice dynamics, sea-ice thermodynamics, atmospheric boundary layer processes, and the upper ocean. Similarly, advancing process understanding of the driving mechanisms of rapid glacier changes requires targeted field campaigns at the critical ice-ocean interface involving both glaciologists and oceanographers. This requires a paradigm shift in the design of field campaigns (Carmack et al., 2015; Shupe et al., 2016).

We also need to communicate and acknowledge the need for increased diversity and inter-disciplinary focus in the cryospheric research community, where cryospheric, ocean, atmospheric, and other geoscientists, including both observers and modelers, collaborate closely. Models can guide our data collection efforts, providing insight into where best to focus limited resources. By more fully integrating modeling teams into observational programs we can develop the unified monitoring and modeling needed to address the most pressing challenges. Data need to be well-documented and made freely and rapidly available. However, managing the increasing amounts of data, which cover larger scales and come at ever higher resolution, will require technical innovations and international coordination to meet the demands of the scientific community.

Among the many outstanding issues outlined above, perhaps the most important "Grand Challenges" in glacier, snow and sea-ice research pertain to incomplete process understanding, in particular inadequate understanding of ice-ocean interactions and glacier basal boundary conditions; drifting and blowing snow as well as snow microstructure and their effect on the physical behavior at larger scales; and the complex feedback mechanisms controlling sea-ice variations, in particular the polar-cloud feedback. In light of recent rapidly accelerated mass losses and indications of a possibly ongoing irreversible collapse of the marine-based West Antarctic ice sheet, perhaps the most urgent challenge relates to a better understanding of ice sheet

\section{REFERENCES}

Alley, R. B., and Joughin, I. (2012). Modeling ice-sheet flow. Science 336, 551-552. doi: $10.1126 /$ science. 1220530

AMAP (2004). Impacts of a Warming Arctic-Arctic Climate Impact Assessment. Impacts of a Warming Arctic-Arctic Climate Impact Assessment, by Arctic Climate Impact Assessment, 144. ISBN 0521617782. Cambridge: Cambridge University Press. dynamics in this region and resulting consequences for sea-level rise.

Some challenges are common to glacier, snow and sea-ice research. Often relevant processes occur at a wide range of spatial and temporal scales, but control the behavior of the system on broader scales. For example, recent research has shown that iceocean interactions on large scales are influenced by processes at spatial scales of a few meters and temporal scales of minutes, for example, when buoyant plumes rise due to sudden release of fresh water from the bottom of a grounded tidewater glaciers (Xu et al., 2013). Similarly, a short storm can form sastrugis and change snow mass and surface roughness on sea ice (Trujillo et al., 2016) with potentially long-lasting consequences on seaice movement over large scales. Hence, incorporating smallscale processes into large-scale predictive models to an extent necessary to predict the system as a whole is a major task for future generation models. Another example for a challenge common to all three subdisciplines is the coupling of stand-alone models for individual components of the climate-cryosphereocean system in innovative ways such that feedbacks can be accounted for.

The challenges discussed here will require a concerted effort across disciplines and national boundaries. Many recent scientific findings have taken the cryospheric community by surprise defying previous common wisdom. Keeping an open mind for more surprises to come will be crucial to advance cryospheric sciences. Our field is well-equipped to address these challenges in unprecedented multi-disciplinary and collaborative manners.

\section{AUTHOR CONTRIBUTIONS}

$\mathrm{RH}$ led the study. JH and ML wrote the sea-ice and snow chapter, respectively, and $\mathrm{RH}$ wrote the remaining chapters. All authors provided comments and edits on the entire manuscript.

\section{FUNDING}

RH was supported by NSF grants \#1604058 and \#1543432. JH was supported by ONR award number N000141210470. ML was supported by the Swiss National Science Foundation.

\section{ACKNOWLEDGMENTS}

Comments by M. Truffer, A. Aschwanden, and C. Kienholz and a thorough review by Jack Kohler helped to improve the manuscript. 
Baldauf, M., Seifert, A., Förstner, J., Majewski, D., Raschendorfer, M., and Reinhardt, T. (2011). Operational convective-scale numerical weather prediction with the COSMO model: description and sensitivities. Mon. Weather Rev. 139, 3887-3905. doi: 10.1175/MWR-D-10-05013.1

Bamber, J. L., Griggs, J. A., Hurkmans, R. T. W. L., Dowdeswell, J. A., Gogineni, S. P., Howat, I., et al. (2013). A new bed elevation dataset for Greenland. Cryosphere 7, 499-510. doi: 10.5194/tc-7-499-2013

Banwell, A. F., MacAyeal, D. R., and Sergienko, O. V. (2013). Breakup of the larsen B ice shelf triggered by chain reaction drainage of supraglacial lakes. Geophys. Res. Lett. 40, 5872-5876. doi: 10.1002/2013GL057694

Bartholomaus, T. C., Larsen, C. F., and O'Neel, S. (2013). Does calving matter? Evidence for significant submarine melt. Earth Planet. Sci. Lett. 380, 21-30. doi: 10.1016/j.epsl.2013.08.014

Beer, C. (2016). Permafrost sub-grid heterogeneity of soil properties key for 3-D soil processes and future climate projections. Front. Earth Sci. 4:81. doi: $10.3389 /$ feart.2016.00081

Bekryaev, R. V., Polyakov, I. V., and Alexeev, V. A. (2010). Role of polar amplification in long-term surface air temperature variations and modern Arctic warming. J. Clim. 23, 3888-3906. doi: 10.1175/2010JCLI3297.1

Bintanja, R., Van Oldenborgh, G., Drijfhout, S., Wouters, B., and Katsman, C. (2013). Important role for ocean warming and increased ice-shelf melt in Antarctic sea-ice expansion. Nat. Geosci. 6, 376-379. doi: 10.1038/ngeo1767

Blanchard-Wrigglesworth, E., Bitz, C. M., and Holland, M. M. (2011). Influence of initial conditions and climate forcing on predicting Arctic sea ice. Geophys. Res. Lett. 38:L18503. doi: 10.1029/2011GL048807

Brinkerhoff, D., Aschwanden, A., and Truffer, M. (2016). Bayesian inference of subglacial topography using mass conservation. Front. Earth Sci. 4:8. doi: $10.3389 /$ feart.2016.00008

Bueler, E., and Pelt, W. V. (2015). Mass-conserving subglacial hydrology in the parallel ice sheet model version 0.6. Geosci. Model Dev. 8, 1613-1635. doi: 10.5194/gmd-8-1613-2015

Carmack, E., Polyakov, I., Padman, L., Fer, I., Hunke, E., Hutchings, J., et al. (2015). Toward quantifying the increasing role of oceanic heat in sea ice loss in the New Arctic. Bull. Am. Meteorol. Soc. 96, 2079-2105. doi: 10.1175/BAMS-D-13-00177.1

Carmack, E. C. (1990). Large-scale physical oceanography of polar oceans. Polar Oceanogr. A phys. Sci. 171-222. doi: 10.1016/B978-0-12-653031-5.50009-6

Chu, V. W. (2014). Greenland ice sheet hydrology: a review. Prog. Phys. Geography 38, 19-54. doi: 10.1177/0309133313507075

Cook, S., Rutt, I., Murray, T., Luckman, A., Zwinger, T., Selmes, N., et al. (2014). Modelling environmental influences on calving at Helheim Glacier in eastern Greenland. Cryosphere 8, 827-841. doi: 10.5194/tc-8-827-2014

Cullather, R., Nowicki, S., Zhao, B., and Koenig, L. (2016). A characterization of Greenland Ice Sheet surface melt and runoff in contemporary reanalyses and a regional climate model. Front. Earth Sci. 4:10. doi: 10.3389/feart.2016.00010

De Conto, R. M., and Pollard, D. (2016). Contribution of Antarctica to past and future sea-level rise. Nature 531, 591-597. doi: 10.1038/nature17145

Eicken, H., Grenfell, T. C., Perovich, D. K., Richter-Menge, J. A., and Frey, K. (2004). Hydraulic controls of summer Arctic pack ice albedo. J. Geophys. Res. Oceans 109:C08007. doi: 10.1029/2003JC001989

Eisenman, I. (2010). Geographic muting of changes in the Arctic sea ice cover. Geophys. Res. Lett. 37:L16501. doi: 10.1029/2010GL043741

Ettema, J., van den Broeke, M. R., van Meijgaard, E., van de Berg, W. J., Bamber, J. L., Box, J. E., et al. (2009). Higher surface mass balance of the Greenland ice sheet revealed by high-resolution climate modeling. Geophys. Res. Lett. 36:L12501. doi: 10.1029/2009GL038110

Fahnestock, M., Scambos, T., Moon, T., Gardner, A., Haran, T., and Klinger, M. (2016). Rapid large-area mapping of ice flow using Landsat 8. Remote Sens. Environ. 185, 84-94. doi: 10.1016/j.rse.2015.11.023

Farinotti, D., Brinkerhoff, D. J., Clarke, G. K. C., Fürst, J. J., Frey, H., Gantayat, P., et al. (2017). How accurate are estimates of glacier ice thickness? Results from ITMIX, the ice thickness models intercomparison eXperiment. Cryosphere 11, 949-970. doi: 10.5194/tc-11-949-2017

Favier, L., Durand, G., Cornford, S., Gudmundsson, G., Gagliardini, O., GilletChaulet, F., et al. (2014). Retreat of Pine Island Glacier controlled by marine ice-sheet instability. Nat. Clim. Chang. 4, 117-121. doi: 10.1038/nclimate2094

Fetterer, F., and Untersteiner, N. (1998). Observations of melt ponds on Arctic sea ice. J. Geophys. Res. 103, 821-824. doi: 10.1029/98JC02034
Fettweis, X., Hanna, E., Gallée, H., Huybrechts, P., and Erpicum, M. (2008) Estimation of the Greenland ice sheet surface mass balance for the 20th and 21st centuries. Cryosphere 2, 117-129. doi: 10.5194/tc-2-117-2008

Flocco, D., Feltham, D. L., and Turner, A. K. (2010). Incorporation of a physically based melt pond scheme into the sea ice component of a climate model. $J$. Geophys. Res. Oceans 115:C08012. doi: 10.1029/2009JC005568

Flocco, D., Schroeder, D., Feltham, D. L., and Hunke, E. C. (2012). Impact of melt ponds on Arctic sea ice simulations from 1990 to 2007. J. Geophys. Res. Oceans 117:C09032. doi: 10.1029/2012JC008195

Forster, R. R., van den Broeke, M. R., Miège, C., Burgess, E. W., van Angelen, J. H., Lenaerts, J. T., et al. (2014). Extensive liquid meltwater storage in firn within the Greenland ice sheet. Nat. Geosci. 7, 95-98. doi: 10.1038/ngeo2043

Fountain, A. G., and Walder, J. S. (1998). Water flow through temperate glaciers. Rev. Geophys. 36, 299-328. doi: 10.1029/97RG03579

Fretwell, P., Pritchard, H. D., Vaughan, D. G., Bamber, J., Barrand, N., Bell, R., et al. (2013). Bedmap2: improved ice bed, surface and thickness datasets for Antarctica. Cryosphere 7, 375-393. doi: 10.5194/tc-7-375-2013

Fricker, H. A., Scambos, T., Bindschadler, R., and Padman, L. (2007). An active subglacial water system in West Antarctica mapped from space. Science 315, 1544-1548. doi: 10.1126/science.1136897

Fried, M., Catania, G., Bartholomaus, T., Duncan, D., Davis, M., Stearns, L., et al. (2015). Distributed subglacial discharge drives significant submarine melt at a Greenland tidewater glacier. Geophys. Res. Lett. 42, 9328-9336. doi: 10.1002/2015GL065806

Gallee, H., Trouvilliez, A., Agosta, C., Genthon, C., Favier, V., and NaaimBouvet, F. (2013). Transport of snow by the wind: a comparison between observations in Adelie Land, Antarctica, and simulations made with the regional climate model, MAR. Boundary Layer Meteorol. 146, 133-147. doi: $10.1007 / \mathrm{s} 10546-012-9764-\mathrm{z}$

Gallet, J. C., Domine, F., Zender, C. S., and Picard, G. (2009). Measurement of the specific surface area of snow using infrared reflectance in an integrating sphere at 1310 and $1550 \mathrm{~nm}$. Cryosphere 3, 167-182. doi: 10.5194/tc-3-167-2009

Gardner, A. S., Moholdt, G., Cogley, J. G., Wouters, B., Arendt, A. A., Wahr, J., et al. (2013). A reconciled estimate of glacier contributions to sea level rise: 2003 to 2009. Science 340, 852-857. doi: 10.1126/science. 1234532

Giles, K. A., Laxon, S. W., Ridout, A. L., Wingham, D. J., and Bacon, S. (2012). Western Arctic Ocean freshwater storage increased by wind-driven spin-up of the Beaufort Gyre. Nat. Geosci. 5, 194-197. doi: 10.1038/ngeo1379

Greuell, W., and Böhm, R. (1998). $2 \mathrm{~m}$ temperatures along melting mid-latitude glaciers, and implications for the sensitivity of the mass balance to variations in temperature. J. Glaciol. 44, 9-20. doi: 10.1017/S0022143000002306

Grunewald, T., Buhler, Y., and Lehning, M. (2014). Elevation dependency of mountain snow depth. Cryosphere 8, 2381-2394. doi: 10.5194/tc-8-2381-2014

Guemas, V., Blanchard-Wrigglesworth, E., Chevallier, M., Day, J. J., Déqué, M., Doblas-Reyes, F. J., et al. (2014). A review on Arctic sea-ice predictability and prediction on seasonal to decadal time-scales. Q. J. R. Meteorol. Soc. 142, 546-561. doi: 10.1002/qj.2401

Harper, J., Humphrey, N., Pfeffer, W., Brown, J., and Fettweis, X. (2012). Greenland ice-sheet contribution to sea-level rise buffered by meltwater storage in firn. Nature 491, 240-243. doi: 10.1038/nature11566

Hattermann, T., Smedsrud, L. H., Nøst, O. A., Lilly, J. M., and Galton-Fenzi, B. K. (2014). Eddy-resolving simulations of the Fimbul Ice shelf cavity circulation: basal melting and exchange with open ocean. Ocean Model. 82, 28-44. doi: 10.1016/j.ocemod.2014.07.004

Helm, V., Humbert, A., and Miller, H. (2014). Elevation and elevation change of Greenland and Antarctica derived from CryoSat-2. Cryosphere 8, 1539-1559. doi: $10.5194 /$ tc-8-1539-2014

Hock, R. (2005). Glacier melt: a review of processes and their modelling. Prog. Phys. Geography 29, 362-391. doi: 10.1191/0309133305pp453ra

Holland, D. M., Thomas, R. H., De Young, B., Ribergaard, M. H., and Lyberth, B. (2008). Acceleration of Jakobshavn Isbrae triggered by warm subsurface ocean waters. Nat. Geosci. 1, 659-664. doi: 10.1038/ngeo316

Holland, M. M., Bitz, C. M., and Tremblay, B. (2006). Future abrupt reductions in the summer Arctic sea ice. Geophys. Res. Lett. 33:L23503. doi: 10.1029/2006GL028024

Howat, I., Negrete, A., and Smith, B. (2014). The Greenland Ice Mapping Project (GIMP) land classification and surface elevation data sets. Cryosphere 8, 1509-1518. doi: 10.5194/tc-8-1509-2014 
Howat, I. M., Joughin, I., and Scambos, T. A. (2007). Rapid changes in ice discharge from Greenland outlet glaciers. Science 315, 1559-1561. doi: $10.1126 /$ science. 1138478

Huss, M., and Hock, R. (2015). A new model for global glacier change and sea-level rise. Front. Earth Sci. 3:54. doi: 10.3389/feart.2015.00054

Hutchings, J. K., and Perovich, D. K. (2015). Preconditioning of the 2007 seaice melt in the eastern Beaufort Sea, Arctic Ocean. Ann. Glaciol. 56, 94-98. doi: 10.3189/2015AoG69A006

Iken, A., and Bindschadler, R. A. (1986). Combined measurements of subglacial water pressure and surface velocity of Findelengletscher, Switzerland: conclusions about drainage system and sliding mechanism. J. Glaciol. 32, 101-119. doi: $10.1017 /$ S0022143000006936

IPCC (2007). "Climate change 2007: The Physical Science Basis," in Contribution of Working Group 1 to the Fourth Assessment Report of the Interbovernmental Panel on Climate Change, The Physical Science Basis, eds S. Solomon, D. Qin, M. Manning, Z. Chen, M. Marquis, K. B. Averyt, M. Tignor, and H. L. Miller (Cambridge, UK; New York, NY: Cambridge University Press), 996 p.

IPCC (2013). "Climate change 2013: The Physical Science Basis," in Contribution of Working Group I to the fifth Assessment Report of the intergovernmental Panel on Climate Change, The Physical Science Basis, eds T. F. Stocker, D. Quin, G.K. Plattner, M. Tignor, S. K. Allen, J. Boschung, A. Nauels, Y. Xia, V. Bex, and P. M. Midgley (Cambridge, UK; New York, NY: Cambridge University Press), $1535 \mathrm{p}$.

Itoh, M., Inoue, J., Shimada, K., Zimmermann, S., Kikuchi, T., Hutchings, J., et al. (2011). Acceleration of sea-ice melting due to transmission of solar radiation through ponded ice area in the Arctic Ocean: results of in situ observations from icebreakers in 2006 and 2007. Ann. Glaciol. 52, 249-260. doi: $10.3189 / 172756411795931471$

Jackson, J. M., Carmack, E. C., McLaughlin, F. A., Allen, S. E., and Ingram R. G. (2010). Identification, characterization, and change of the near-surface temperature maximum in the Canada Basin, 1993-2008. J. Geophys. Res. 115:C05021. doi: 10.1029/2009JC005265

Jackson, J. M., Williams, W. J., and Carmack, E. C. (2012). Winter sea-ice melt in the Canada Basin, Arctic Ocean. Geophys. Res. Lett. 39:L03603. doi: 10.1029/2011GL050219

Jenkins, A. (2011). Convection-driven melting near the grounding lines of ice shelves and tidewater glaciers. J. Phys. Oceanogr. 41, 2279-2294. doi: 10.1175/JPO-D-11-03.1

Joughin, I., Abdalati, W., and Fahnestock, M. (2004). Large fluctuations in speed on Greenland's Jakobshavn Isbrae glacier. Nature 432, 608-610. doi: $10.1038 /$ nature 03130

Joughin, I., and Alley, R. B. (2011). Stability of the West Antarctic ice sheet in a warming world. Nat. Geosci. 4, 506-513. doi: 10.1038/ngeo1194

Joughin, I., Howat, I., Alley, R. B., Ekstrom, G., Fahnestock, M., Moon, T., et al. (2008). Ice-front variation and tidewater behavior on Helheim and Kangerdlugssuaq Glaciers, Greenland. J. Geophys. Res. Earth Surface 113:F01004. doi: 10.1029/2007JF000837

Joughin, I., Smith, B. E., and Medley, B. (2014). Marine ice sheet collapse potentially under way for the Thwaites Glacier Basin, West Antarctica. Science 344, 735-738. doi: 10.1126/science. 1249055

Kargel, J. S., Leonard, G. J., Bishop, M. P., Käb, A., and Raup, B. H. (eds.). (2014). Global Land Ice Measurements from Space. Berlin; Heidelberg: Springer-Verlag. doi: 10.1007/978-3-540-79818-7_33

Karlsson, J., and Svensson, G. (2013). Consequences of poor representation of Arctic sea-ice albedo and cloud-radiation interactions in the CMIP5 model ensemble. Geophys. Res. Lett. 40, 4374-4379. doi: 10.1002/grl.50768

Kattsov, V. M., Ryabinin, V. E., Overland, J. E., Serreze, M. C., Visbeck, M., Walsh, J. E., et al. (2010). Arctic sea-ice change: a grand challenge of climate science. J. Glaciol. 56, 1115-1121. doi: 10.3189/002214311796406176

Kay, J. E., and Gettelman, A. (2009). Cloud influence on and response to seasonal Arctic sea ice loss. J. Geophys. Res. Atmos. 114:D18204. doi: 10.1029/2009JD011773

Kay, J. E., L'Ecuyer, T., Gettelman, A., Stephens, G., and O'Dell, C. (2008). The contribution of cloud and radiation anomalies to the 2007 Arctic sea ice extent minimum. Geophys. Res. Lett. 35:L08503. doi: 10.1029/2008GL033451

Khan, S. A., Aschwanden, A., Bjørk, A. A., Wahr, J., Kjeldsen, K. K., and Kjær, K. H. (2015). Greenland ice sheet mass balance: a review. Rep. Prog. Phys. 78:046801. doi: $10.1088 / 0034-4885 / 78 / 4 / 046801$
Kirchner, P. B., Bales, R. C., Molotch, N. P., Flanagan, J., and Guo, Q. (2014), LiDAR measurement of seasonal snow accumulation along an elevation gradient in the southern Sierra Nevada, California. Hydrol. Earth Syst. Sci. 18, 4261-4275. doi: 10.5194/hess-18-4261-2014

Krishfield, R. A., and Perovich, D. K. (2005). Spatial and temporal variability of oceanic heat flux to the Arctic ice pack. J. Geophys. Res. Oceans 110:C07021. doi: 10.1029/2004JC002293

Krol, Q., and Löwe, H. (2016). Relating optical and microwave grain metrics of snow: the relevance of grain shape. Cryosphere 10, 2847-2863. doi: $10.5194 / \mathrm{tc}-10-2847-2016$

Kwok, R., and Cunningham, G. (2008). ICESat over Arctic sea ice: estimation of snow depth and ice thickness. J. Geophys. Res. Oceans 113:C08010. doi: 10.1029/2008JC004753

Kwok, R., and Cunningham, G. F. (2010). Contribution of melt in the Beaufort Sea to the decline in Arctic multiyear sea ice coverage: 1993-2009. Geophys. Res. Lett. 37:L20501. doi: 10.1029/2010GL044678

Kwok, R., Hunke, E. C., Maslowski, W., Menemenlis, D., and Zhang, J. (2008). Variability of sea ice simulations assessed with RGPS kinematics. J. Geophys. Res. Oceans 113:C11012. doi: 10.1029/2008JC004783

Kwok, R., and Untersteiner, N. (2011). The thinning of Arctic sea ice. Phys. Today 64, 36-41. doi: 10.1063/1.3580491

Laxon, S., Peacock, N., and Smith, D. (2003). High interannual variability of sea ice thickness in the Arctic region. Nature 425, 947-950. doi: 10.1016/S0165-232X(02)00073-3

Lehning, M., Bartelt, P., Brown, B., Fierz, C., and Satyawali, P. (2002). A physical SNOWPACK model for the Swiss avalanche warning part II: snow microstructure. Cold Regions Sci. Technol. 35, 147-167. doi: $10.1016 / \mathrm{S} 0165-232 \mathrm{X}(02) 00073-3$

Lenaerts, J. T. M., van den Broeke, M. R., Déry, S. J., van Meijgaard, E., van de Berg, W. J., Palm, S. P., et al. (2012). Modeling drifting snow in Antarctica with a regional climate model: 1. Methods and model evaluation. J. Geophys. Res. Atmos. 117:D05108. doi: 10.1029/2011JD016145

Lenaerts, J. T. M., van Meijgaard, E., van den Broeke, M. R., Ligtenberg, S. R. M., Horwath, M., and Isaksson, E. (2013). Recent snowfall anomalies in Dronning Maud Land, East Antarctica, in a historical and future climate perspective. Geophys. Res. Lett. 40, 2684-2688. doi: 10.1002/grl.50559

Lowe, H., Riche, F., and Schneebeli, M. (2013). A general treatment of snow microstructure exemplified by an improved relation for thermal conductivity. Cryosphere 7, 1473-1480. doi: 10.5194/tc-7-1473-2013

Lowe, H., and van Herwijnen, A. (2012). A Poisson shot noise model for micro-penetration of snow. Cold Reg. Sci. Technol. 70, 62-70. doi: 10.1016/j.coldregions.2011.09.001

Machguth, H., MacFerrin, M., van As, D., Charalampidis, C., Colgan, W., Fausto, R. S., et al. (2016). Greenland meltwater storage in firn limited by near-surface ice formation. Nat. Clim. Change 6, 390-393. doi: 10.1038/nclimate2899

Martin, T., Steele, M., and Zhang, J. (2014). Seasonality and long-term trend of Arctic Ocean surface stress in a model. J. Geophys. Res. Oceans 119, 1723-1738. doi: 10.1002/2013JC009425

Maslanik, J., Stroeve, J., Fowler, C., and Emery, W. (2011). Distribution and trends in Arctic sea ice age through spring 2011. Geophys. Res. Lett. 38:L13502. doi: 10.1029/2011GL047735

Maykut, G. A. (1982). Large-scale heat exchange and ice production in the central Arctic. J. Geophys. Res. Oceans 87, 7971-7984. doi: 10.1029/JC087iC10p07971

McMillan, M., Shepherd, A., Sundal, A., Briggs, K., Muir, A., Ridout, A., et al. (2014). Increased ice losses from Antarctica detected by CryoSat-2. Geophys. Res. Lett. 41, 3899-3905. doi: 10.1002/2014GL060111

McNabb, R., Hock, R., O'Neel, S., Rasmussen, L., Ahn, Y., Braun, M., et al. (2012). Using surface velocities to calculate ice thickness and bed topography: a case study at Columbia Glacier, Alaska, U. S. A. J. Glaciol. 58, 1151-1164. doi: 10.3189/2012JoG11J249

McPhee, M., Kwok, R., Robins, R., and Coon, M. (2005). Upwelling of Arctic pycnocline associated with shear motion of sea ice. Geophys. Res. Lett. 32:L10616. doi: 10.1029/2004GL021819

McPhee, M. G. (2013). Intensification of geostrophic currents in the Canada Basin, Arctic Ocean. J. Clim. 26, 3130-3138. doi: 10.1175/JCLI-D-12-00289.1

Meierbachtol, T., Harper, J., and Humphrey, N. (2013). Basal drainage system response to increasing surface melt on the Greenland Ice Sheet. Science 341, 777-779. doi: 10.1126/science. 1235905 
Mercer, J. H. (1978). West Antarctic ice sheet and $\mathrm{CO}_{2}$ greenhouse effect-A threat of disaster. Nature 271, 321-325. doi: 10.1038/271321a0

Miles, M. W., Divine, D. V., Furevik, T., Jansen, E., Moros, M., and Ogilvie, A. E. (2014). A signal of persistent Atlantic multidecadal variability in Arctic sea ice. Geophys. Res. Lett. 41, 463-469. doi: 10.1002/2013GL058084

Moon, T., Joughin, I., and Smith, B. (2015). Seasonal to multiyear variability of glacier surface velocity, terminus position, and sea ice/ice melange in northwest Greenland. J. Geophys. Res. Earth Surf. 120, 818-833. doi: 10.1002/2015JF003494

Moon, T., Joughin, I., Smith, B., and Howat, I. (2012). 21st-century evolution of Greenland outlet glacier velocities. Science 336, 576-578. doi: $10.1126 /$ science. 1219985

Moon, T., Joughin, I., Smith, B., van den Broeke, M. R., van de Berg, W. J., Noel, B., et al. (2014). Distinct patterns of seasonal Greenland glacier velocity. Geophys. Res. Lett. 41, 7209-7216. doi: 10.1002/2014GL061836

Morlighem, M., Rignot, E., Mouginot, J., Seroussi, H., and Larour, E. (2014). Deeply incised submarine glacial valleys beneath the Greenland ice sheet. Nat. Geosci. 7, 418-422. doi: 10.1038/ngeo2167

Morison, J., Kwok, R., Peralta-Ferriz, C., Alkire, M., Rigor, I., Andersen, R., et al. (2012). Changing arctic ocean freshwater pathways. Nature 481, 66-70. doi: $10.1038 /$ nature 10705

Mott, R., Daniels, M., and Lehning, M. (2015). Atmospheric flow development and associated changes in turbulent sensible heat flux over a patchy mountain snow cover. J. Hydrometeorol. 16, 1315-1340. doi: 10.1175/JHM-D-14-0036.1

Mott, R., Paterna, E., Horender, S., Crivelli, P., and Lehning, M. (2016). Wind tunnel experiments: cold-air pooling and atmospheric decoupling above a melting snow patch. Cryosphere 10, 445-458. doi: 10.5194/tc-10-445-2016

Mott, R., Scipion, D., Schneebeli, M., Dawes, N., Berne, A., and Lehning, M. (2014). Orographic effects on snow deposition patterns in mountainous terrain. J. Geophys. Res. Atmos. 119, 1419-1439. doi: 10.1002/2013JD 019880

Motyka, R. J., Dryer, W. P., Amundson, J., Truffer, M., and Fahnestock, M. (2013). Rapid submarine melting driven by subglacial discharge, LeConte Glacier, Alaska. Geophys. Res. Lett. 40, 5153-5158. doi: 10.1002/grl.51011

Motyka, R. J., Truffer, M., Fahnestock, M., Mortensen, J., Rysgaard, S., and Howat, I. (2011). Submarine melting of the 1985 Jakobshavn Isbrae floating tongue and the triggering of the current retreat. J. Geophys. Res. Earth Surf. 116:F01007. doi: 10.1029/2009JF001632

Mouginot, J., Rignot, E., and Scheuchl, B. (2014). Sustained increase in ice discharge from the Amundsen Sea Embayment, West Antarctica, from 1973 to 2013. Geophys. Res. Lett. 41, 1576-1584. doi: 10.1002/2013GL059069

Murray, T., Scharrer, K., James, T. D., Dye, S. R., Hanna, E., Booth, A. D., et al. (2010). Ocean regulation hypothesis for glacier dynamics in southeast Greenland and implications for ice sheet mass changes. J. Geophys. Res. Earth Surf. 115:F03026. doi: 10.1029/2009JF001522

Nghiem, S. V., Rigor, I. G., Perovich, D. K., Clemente-Colón, P., Weatherly, J. W., and Neumann, G. (2007). Rapid reduction of Arctic perennial sea ice. Geophys. Res. Lett. 34:L19504. doi: 10.1029/2007GL031138

Nicolaus, M., Katlein, C., Maslanik, J., and Hendricks, S. (2012). Changes in Arctic sea ice result in increasing light transmittance and absorption. Geophys. Res. Lett. 39:L24501. doi: 10.1029/2012GL053738

Notz, D. (2015). How well must climate models agree with observations? Philos. Trans. R. Soc. A 373:20140164. doi: 10.1098/rsta.2014.0164

O'Leary, M., and Christoffersen, P. (2013). Calving on tidewater glaciers amplified by submarine frontal melting. Cryosphere 7, 119-128. doi: $10.5194 /$ tc- $7-119-2013$

Overland, J. E., and Wang, M. (2010). Large-scale atmospheric circulation changes are associated with the recent loss of Arctic sea ice. Tellus A 62, 1-9. doi: $10.1111 /$ j. 1600-0870.2009.00421.x

Palmer, S., Shepherd, A., Nienow, P., and Joughin, I. (2011). Seasonal speedup of the Greenland Ice Sheet linked to routing of surface water. Earth Planet. Sci. Lett. 302, 423-428. doi: 10.1016/j.epsl.2010.12.037

Pattyn, F. (2010). Antarctic subglacial conditions inferred from a hybrid ice sheet/ice stream model. Earth Planet. Sci. Lett. 295, 451-461. doi: 10.1016/j.epsl.2010.04.025

Perovich, D., Jones, K., Light, B., Eicken, H., Markus, T., Stroeve, J., et al. (2011). Solar partitioning in a changing Arctic sea-ice cover. Ann. Glaciol. 52, 192-196. doi: $10.3189 / 172756411795931543$
Petrich, C., Eicken, H., Polashenski, C. M., Sturm, M., Harbeck, J. P., Perovich, D. K., et al. (2012). Snow dunes: a controlling factor of melt pond distribution on Arctic sea ice. J. Geophys. Res. Oceans 117:C09029. doi: 10.1029/2012JC008192

Petty, A. A., Hutchings, J. K., Richter-Menge, J. A., and Tschudi, M. A. (2016). Sea ice circulation around the Beaufort Gyre: the changing role of wind forcing and the sea ice state. J. Geophys. Res. Oceans 121, 3278-3296. doi: 10.1002/2015JC010903

Pfeffer, W. T., Arendt, A. A., Bliss, A., Bolch, T., Cogley, J. G., Gardner, A. S., et al. (2014). The Randolph Glacier Inventory: a globally complete inventory of glaciers. J. Glaciol. 60, 537-552. doi: 10.3189/2014JoG13J176

Pithan, F., Medeiros, B., and Mauritsen, T. (2014). Mixed-phase clouds cause climate model biases in Arctic wintertime temperature inversions. Clim. Dyn. 43, 289-303. doi: 10.1007/s00382-013-1964-9

Polyakov, I. V., Bekryaev, R. V., Alekseev, G. V., Bhatt, U. S., Colony, R. L., Johnson, M. A., et al. (2003). Variability and trends of air temperature and pressure in the maritime Arctic, 1875-2000. J. Clim. 16, 2067-2077. doi: 10.1175/1520-0442(2003)016<2067:VATOAT >2.0.CO;2

Polyakov, I. V., Pnyushkov, A. V., Alkire, M. B., Ashik, I. M., Baumann, T. M., Carmack, E. C., et al. (2017). Greater role for Atlantic inflows on seaice loss in the Eurasian Basin of the Arctic Ocean. Science 356, 285-291. doi: $10.1126 /$ science.aai8204

Polyakov, I. V., Pnyushkov, A. V., and Timokhov, L. A. (2012). Warming of the Intermediate Atlantic Water of the Arctic Ocean in the 2000s. J. Clim. 25, 8362-8370. doi: 10.1175/JCLI-D-12-00266.1

Post, A., O'Neel, S., Motyka, R. J., and Streveler, G. (2011). A complex relationship between calving glaciers and climate. EOS 92, 305-306. doi: 10.1029/2011EO370001

Pritchard, H. D., Arthern, R. J., Vaughan, D. G., and Edwards, L. A. (2009). Extensive dynamic thinning on the margins of the Greenland and Antarctic ice sheets. Nature 461, 971-975. doi: 10.1038/nature08471

Raup, B., Kääb, A., Kargel, J. S., Bishop, M. P., Hamilton, G., Lee, E., et al. (2007). Remote sensing and GIS technology in the Global Land Ice Measurements from Space (GLIMS) project. Comput. Geosci. 33, 104-125. doi: 10.1016/j.cageo.2006.05.015

Reager, J. T., Gardner, A. S., Famiglietti, J. S., Wiese, D. N., Eicker, A., and Lo, M. H. (2016). A decade of sea level rise slowed by climate-driven hydrology. Science 351, 699-703. doi: $10.1126 /$ science.aad 8386

Rignot, E., and Jacobs, S. S. (2002). Rapid bottom melting widespread near Antarctic ice sheet grounding lines. Science 296, 2020-2023. doi: $10.1126 /$ science. 1070942

Rignot, E., and Kanagaratnam, P. (2006). Changes in the velocity structure of the Greenland Ice Sheet. Science 311, 986-990. doi: 10.1126/science.1121381

Rignot, E., Mouginot, J., and Scheuchl, B. (2011). Ice flow of the Antarctic ice sheet. Science 333, 1427-1430. doi: 10.1126/science. 1208336

Rignot, E., Mouginot, J., Morlighem, M., Seroussi, H., and Scheuchl, B. (2014). Widespread, rapid grounding line retreat of Pine Island, Thwaites, Smith, and Kohler glaciers, West Antarctica, from 1992 to 2011. Geophys. Res. Lett. 41, 3502-3509. doi: 10.1002/2014GL060140

Rigor, I. G., and Wallace, J. M. (2004). Variations in the age of Arctic sea-ice and summer sea-ice extent. Geophys. Res. Lett. 31:L09401. doi: 10.1029/2004GL019492

Ritz, C., Edwards, T. L., Durand, G., Payne, A. J., Peyaud, V., and Hindmarsh, R. C. (2015). Potential sea-level rise from Antarctic ice-sheet instability constrained by observations. Nature 528, 115-118. doi: 10.1038/nature16147

Rösel, A., and Kaleschke, L. (2012). Exceptional melt pond occurrence in the years 2007 and 2011 on the Arctic sea ice revealed from MODIS satellite data. J. Geophys. Res. Oceans 117:C05018. doi: 10.1029/2011JC 007869

Schleef, S., and Lowe, H. (2013). X-ray microtomography analysis of isothermal densification of new snow under external mechanical stress. J. Glaciol. 59, 233-243. doi: 10.3189/2013JoG12J076

Schlögl, S., Marty, C., Bavay, M., and Lehning, M. (2016). Sensitivity of Alpine3D modeled snow cover to modifications in DEM resolution, station coverage and meteorological input quantities. Environ. Model. Softw. 83, 387-396. doi: 10.1016/j.envsoft.2016.02.017

Schmucki, E., Marty, C., Fierz, C., and Lehning, M. (2015). Simulations of 21st century snow response to climate change in Switzerland from a set of RCMs. Int. J. Climatol. 35, 3262-3273. doi: 10.1002/joc.4205 
Schoof, C. (2010). Ice-sheet acceleration driven by melt supply variability. Nature 468, 803-806. doi: 10.1038/nature09618

Schweiger, A., Lindsay, R., Zhang, J., Steele, M., Stern, H., and Kwok, R. (2011). Uncertainty in modeled Arctic sea ice volume. J. Geophys. Res. Oceans 116:C00D06. doi: 10.1029/2011JC007084

Screen, J. A., and Simmonds, I. (2010). The central role of diminishing sea ice in recent Arctic temperature amplification. Nature 464, 1334-1337. doi: 10.1038/nature09051

Sevruk, B., and Mieglitz, K. (2002). The effect of topography, season and weather situation on daily precipitation gradients in 60 Swiss valleys. Water Sci. Technol. $45,41-48$.

Sevruk, B., Ondras, M., and Chvila, B. (2009). The WMO precipitation measurement intercomparisons. Atmos. Res. 92, 376-380. doi: $10.1016 /$ j.atmosres.2009.01.016

Shea, J. M., and Moore, R. D. (2010). Prediction of spatially distributed regionalscale fields of air temperature and vapor pressure over mountain glaciers. J. Geophys. Res. Atmos. 115:D23107. doi: 10.1029/2010JD014351

Shepherd, A., Ivins, E. R., Geruo, A., Barletta, V. R., Bentley, M. J., Bettadpur, S., et al. (2012). A reconciled estimate of ice-sheet mass balance. Science 338, 1183-1189. doi: 10.1126/science. 1228102

Shimada, K., Kamoshida, T., Itoh, M., Nishino, S., Carmack, E., McLaughlin, F., et al. (2006). Pacific Ocean inflow: influence on catastrophic reduction of sea ice cover in the Arctic Ocean. Geophys. Res. Lett. 33:L08605. doi: $10.1029 / 2005$ GL025624

Skyllingstad, E. D., Shell, K. M., Collins, L., and Polashenski, C. (2015). Simulation of the melt season using a resolved sea ice model with snow cover and melt ponds. J. Geophys. Res. Oceans 120, 5194-5215. doi: 10.1002/2014JC010569

Slater, D., Nienow, P., Cowton, T., Goldberg, D., and Sole, A. (2015). Effect of near-terminus subglacial hydrology on tidewater glacier submarine melt rates. Geophys. Res. Lett. 42, 2861-2868. doi: 10.1002/2014GL062494

Smedsrud, L. H., Halvorsen, M. H., Stroeve, J. C., Zhang, R., and Kloster, K. (2017). Fram Strait sea ice export variability and September Arctic sea ice extent over the last 80 years. Cryosphere 11, 65-79. doi: 10.5194/tc-11-65-2017

Stearns, L. A., and Hamilton, G. S. (2007). Rapid volume loss from two East Greenland outlet glaciers quantified using repeat stereo satellite imagery. Geophys. Res. Lett. 34:L05503. doi: 10.1029/2006GL028982

Steele, M., Zhang, J., and Ermold, W. (2010). Mechanisms of summertime upper Arctic Ocean warming and the effect on sea ice melt. J. Geophys. Res. Oceans 115:C11004. doi: 10.1029/2009JC005849

Stewart, E. J., Howell, S. E. L., Draper, D., Yackel, J., and Tivy, A. (2007). Sea ice in Canada's Arctic: implications for cruise tourism. Arctic 60, 370-380. Available online at: http://www.jstor.org/stable/40512960

Straneo, F., Hamilton, G. S., Sutherland, D. A., Stearns, L. A., Davidson, F., Hammill, M. O., et al. (2010). Rapid circulation of warm subtropical waters in a major glacial Fjord in East Greenland. Nat. Geosci. 3, 182-186. doi: 10.1038/ngeo764

Straneo, F., Heimbach, P., Sergienko, O., Hamilton, G., Catania, G., Griffies, S., et al. (2013). Challenges to understanding the dynamic response of greenland's marine terminating glaciers to oceanic and atmospheric forcing. Bull. Am. Meteorol. Soc. 94, 1131-1144. doi: 10.1175/BAMS-D-12-00100.1

Stroeve, J., and Notz, D. (2015). Insights on past and future sea-ice evolution from combining observations and models. Glob. Planet. Change 135, 119-132. doi: 10.1016/j.gloplacha.2015.10.011

Stroeve, J. C., Kattsov, V., Barrett, A., Serreze, M., Pavlova, T., Holland, M., et al. (2012). Trends in Arctic sea ice extent from CMIP5, CMIP3 and observations. Geophys. Res. Lett. 39:L16502. doi: 10.1029/2012GL052676

Sundal, A. V., Shepherd, A., Nienow, P., Hanna, E., Palmer, S., and Huybrechts, P. (2011). Melt-induced speed-up of Greenland ice sheet offset by efficient subglacial drainage. Nature 469, 521-524. doi: 10.1038/nature 09740

Sutherland, D. A., Straneo, F., Stenson, G. B., Davidson, F. J. M., Hammill, M. O., and Rosing-Asvid, A. (2013). Atlantic water variability on the SE Greenland continental shelf and its relationship to SST and bathymetry. J. Geophys. Res. Oceans 118, 847-855. doi: 10.1029/2012JC008354

Sutterley, T. C., Velicogna, I., Rignot, E., Mouginot, J., Flament, T., van den Broeke, M. R., et al. (2014). Mass loss of the Amundsen Sea Embayment of West Antarctica from four independent techniques. Geophys. Res. Lett. 41, 8421-8428. doi: $10.1002 / 2014$ GL061940
Shupe, M., Barber, D., Dethloff, K., Gerland, S., Inoue, J., Lee, C., et al. (2016). MOSAIC Multidisciplinary Drifting Observatory for the Study of Arctic Climate: Science Plan. International Arctic Science Committee. Available online at: http://iasc.info/images/working-groups/MosaicSciencePlan2016.pdf

Tedstone, A. J., Nienow, P. W., Gourmelen, N., Dehecq, A., Goldberg, D., and Hanna, E. (2015). Decadal slowdown of a land-terminating sector of the Greenland Ice Sheet despite warming. Nature 526, 692-695. doi: 10.1038/nature15722

Timmermans, M. L. (2015). The impact of stored solar heat on Arctic sea ice growth. Geophys. Res. Lett. 42, 6399-6406. doi: 10.1002/2015GL064541

Truffer, M., and Fahnestock, M. (2007). Rethinking ice sheet time scales. Science 315, 1508-1510. doi: 10.1126/science.1140469

Truffer, M., and Motyka, R. (2016). Where glaciers meet water: subaqueous melt and its relevance to glaciers in various settings. Rev. Geophys. 54, 220-239. doi: 10.1002/2015RG000494

Trujillo, E., Leonard, K., Maksym, T., and Lehning, M. (2016). Changes in Snow Distribution and Surface Topography Following a Snowstorm on Antarctic Sea Ice. J. Geophys. Res. Earth Surf. 121, 2172-2191. doi: 10.1002/2016JF003893

Tsamados, M., Feltham, D. L., Schroeder, D., Flocco, D., Farrell, S. L., Kurtz, N., et al. (2014). Impact of variable atmospheric and oceanic form drag on simulations of Arctic sea ice*. J. Phys. Oceanogr. 44, 1329-1353. doi: 10.1175/JPO-D-13-0215.1

Turner, J., Hosking, J. S., Bracegirdle, T. J., Marshall, G. J., and Phillips, T. (2015). Recent changes in Antarctic Sea ice. Philos. Trans. R. Soc. Lond. A Math. Phys. Eng. Sci. 373:20140163. doi: 10.1098/rsta.2014.0163

Van Angelen, J., Lenaerts, J., Lhermitte, S., Fettweis, X., Kuipers Munneke, P., Van den Broeke, M., et al. (2012). Sensitivity of Greenland Ice Sheet surface mass balance to surface albedo parameterization: a study with a regional climate model. Cryosphere 6, 1175-1186. doi: 10.5194/tc-6-1175-2012

Van Angelen, J. M, Lenaerts, J., Van den Broeke, M., Fettweis, X., and Meijgaard, E. V. (2013). Rapid loss of firn pore space accelerates 21st century Greenland mass loss. Geophys. Res. Lett. 40, 2109-2113. doi: 10.1002/grl.50490

van de Wal, R., Boot, W., van den Broeke, M. R., Smeets, C. J. P. P., Reijmer, C. H., Donker, J. J. A., et al. (2008). Large and rapid melt-induced velocity changes in the ablation zone of the Greenland ice sheet. Science 321, 111-113. doi: $10.1126 /$ science. 1158540

Vaughan, D. G., and Arthern, R. (2007). Why is it hard to predict the future of ice sheets? Science 315, 1503-1504. doi: 10.1126/science.1141111

Vavrus, S., Holland, M. M., and Bailey, D. A. (2011). Changes in Arctic clouds during intervals of rapid sea ice loss. Clim. Dyn. 36, 1475-1489. doi: 10.1007/s00382-010-0816-0

Velicogna, I., Sutterley, T. C., and van den Broeke, M. R. (2014). Regional acceleration in ice mass loss from Greenland and Antarctica using GRACE time-variable gravity data. Geophys. Res. Lett. 41, 8130-8137. doi: 10.1002/2014GL061052

Vihma, T., Pirazzini, R., Fer, I., Renfrew, I. A., Sedlar, J., Tjernström, M., et al. (2014). Advances in understanding and parameterization of small-scale physical processes in the marine Arctic climate system: a review. Atmos. Chem. Phys. 14, 9403-9450. doi: 10.5194/acp-14-9403-2014

Vivier, F., Hutchings, J. K., Kawaguchi, Y., Kikuchi, T., Morison, J. H., Lourenço, A., et al. (2016). Sea ice melt onset associated with lead opening during the spring/summer transition near the North Pole. J. Geophys. Res. Oceans 121, 2499-2522. doi: 10.1002/2015JC011588

Vizcaino, M. (2014). Ice sheets as interactive components of Earth System Models: progress and challenges. Wiley Interdiscip. Rev. 5, 557-568. doi: $10.1002 /$ wcc. 285

Vizcaino, M., Mikolajewicz, U., Ziemen, F., Rodehacke, C. B., Greve, R., and Broeke, M. R. (2015). Coupled simulations of Greenland Ice Sheet and climate change up to AD 2300. Geophys. Res. Lett. 42, 3927-3935. doi: 10.1002/2014GL061142

Wingham, D. J., Siegert, M. J., Shepherd, A., and Muir, A. S. (2006). Rapid discharge connects Antarctic subglacial lakes. Nature 440, 1033-1036. doi: $10.1038 /$ nature 04660

Woodgate, R. A., Weingartner, T., and Lindsay, R. (2010). The 2007 Bering Strait oceanic heat flux and anomalous Arctic sea-ice retreat. Geophys. Res. Lett. 37:L01602. doi: 10.1029/2009GL041621

Woodgate, R. A., Weingartner, T. J., and Lindsay, R. (2012). Observed increases in Bering Strait oceanic fluxes from the Pacific to the Arctic from 2001 to 2011 and 
their impacts on the Arctic Ocean water column. Geophys. Res. Lett. 39:L24603. doi: 10.1029/2012GL054092

Xu, Y., Rignot, E., Fenty, I., Menemenlis, D., and Flexas, M. (2013). Subaqueous melting of Store Glacier, west Greenland from three-dimensional, highresolution numerical modeling and ocean observations. Geophys. Res. Lett. 40, 4648-4653. doi: $10.1002 /$ grl.50825

Xu, Y., Rignot, E., Menemenlis, D., and Koppes, M. (2012). Numerical experiments on subaqueous melting of Greenland tidewater glaciers in response to ocean warming and enhanced subglacial discharge. Ann. Glaciol. 53, 229-234. doi: 10.3189/2012AoG60A139

Zhang, J., Lindsay, R., Schweiger, A., and Steele, M. (2013). The impact of an intense summer cyclone on 2012 Arctic sea ice retreat. Geophys. Res. Lett. 40, 720-726. doi: 10.1002/grl.50190

Ziemen, F. A., Hock, R., Aschwanden, A., Khroulev, C., Kienholz, C., Melkonian, A., et al. (2016). Modeling the evolution of the Juneau Icefield between 1971 and 2100 using the Parallel Ice Sheet Model (PISM). J. Glaciol. 62, 199-214. doi: $10.1017 /$ jog. 2016.13

Zwaaftink, C. D. G., Cagnati, A., Crepaz, A., Fierz, C., Macelloni, G., Valt, M., et al. (2013). Event-driven deposition of snow on the Antarctic Plateau: analyzing field measurements with SNOWPACK. Cryosphere 7, 333-347. doi: 10.5194/tc-7-333-2013

Zwally, H. J., Abdalati, W., Herring, T., Larson, K., Saba, J., and Steffen, K. (2002). Surface melt-induced acceleration of Greenland ice-sheet flow. Science 297, 218-222. doi: $10.1126 /$ science. 1072708

Zwally, H. J., and Giovinetto, M. B. (2011). Overview and assessment of Antarctic ice-sheet mass balance estimates: 1992-2009. Surv. Geophys. 32, 351-376. doi: $10.1007 /$ s10712-011-9123-5

Conflict of Interest Statement: The authors declare that the research was conducted in the absence of any commercial or financial relationships that could be construed as a potential conflict of interest.

Copyright (๑) 2017 Hock, Hutchings and Lehning. This is an open-access article distributed under the terms of the Creative Commons Attribution License (CC BY). The use, distribution or reproduction in other forums is permitted, provided the original author(s) or licensor are credited and that the original publication in this journal is cited, in accordance with accepted academic practice. No use, distribution or reproduction is permitted which does not comply with these terms. 